\title{
Irrigation Water Susceptibility Indexing Method, Using Pesticide DRASTIC and Water Quality Index, for Basara Basin; Kurdistan Region-Iraq
}

\author{
Shwan A. Mohammed ${ }^{1}$, Reza Attar Nejad ${ }^{2 *}$, Dara Faeq Hamamin ${ }^{3}$ \\ ${ }^{1}$ Sulaimani Polytechnic University, Sulaimani Technical Institute, Sulaimani-KRG-Iraq/Ph.D. Candidate School of Civil Engineering, University of Tehran, \\ Tehran, Iran \\ ${ }^{2}$ School of Civil Engineering, University of Tehran, Tehran, Iran \\ ${ }^{3}$ Department of Geology, College of Science, University of Sulaimani, Iraq
}

Received: 25/11/2020

Accepted: 07/01/2021

Published: 20/06/2021

\begin{abstract}
The increasing use of chemical fertilizers, with spreading industrial and urbanization activities in the whole area of the Basara basin expected to affect the quantity and quality of water from these sources of pollutants. The main aim of this research revolves around the integration of the intrinsic vulnerability Index (VI) through applying the pesticide DRASTIC method, with the irrigation quality index, to assess the irrigation susceptibility Index (SI) for the basin. The quality of groundwater for its suitability for irrigation purposes was measured by its hydro-chemical parameters in this research. Thirty-one water samples were collected in the studied area during the post-monsoon period of the year 2018. Samples have been tested for both physical and chemical parameters. The Geographic Information System (GIS) has been used for this assessment. The results indicate that water movement directions of streams, the geological formation of aquifers, land slope, and contamination sources have a great impact on water quality, vulnerability, and susceptibility index. The pesticide DRASTIC map categorizes the basin into five classes as (very low, low, moderate, high, and very high). Results show that the most vulnerable area to pollution is those that used for intensive agricultural and industrial sectors, besides the areas with high permeability and lands with minimum surface slopes which are intensively used as cultivated areas. The results indicate that the incorporation of both hydrogeological and hydrochemical datasets enables more realistic evaluations than those of an individual dataset to estimate the groundwater contamination susceptibility of an aquifer. This work offers the decision-makers a clear photo of the quality of irrigation water and the area most vulnerable to contamination. This will be used as the basis for future research to mitigate the effects of vulnerable are as and to establish a new groundwater management strategy in the basin.
\end{abstract}

Keywords: Water quality, Groundwater Contamination, Vulnerability Mapping, Pesticide DRASTIC

\section{Introduction}

Iraq, as arid and semi-arid regions, is specifically dependent on groundwater as the only water source for millions of people for both drinking and irrigation uses, especially after 2003 when domestic, agricultural, and industrial usage of groundwater requirement increased due to the rapid increase of population associated with changing lifestyles [1]. Consequently, groundwater pollution has extremely become a severe problem, particularly in areas where fertilizers are widely used in farmlands. The quality of groundwater supplies is as important as its quantity; hence, it is wise to take proper attention in the quality of groundwater [2-4]. The protection of groundwater contamination is important in the managing of groundwater resources and the evaluation of aquifers vulnerability [5].

Groundwater is the main source of water supply in the Basara basin in the Sulaymani City-Iraq Kurdistan region for domestic, agricultural, recreational, and industrial purposes. This basin is a very fertile agricultural area, industrial and urbanization activities are also dispersed in the whole area. Groundwater in this basin has turned into the only water source because of the limited availability of surface water. Therefore, the quality and quantity of groundwater are important for the socio-economic growth of the country. Water chemistry surveys report from the quality control center of Sulaymani and Sulaymani statistical center since 2010 indicates that the quality of water has been changed in the basin due to the major potential point and non-point contamination sources. Besides, and as a result of these actions, aquifers and ecosystems are vulnerable to substantial impacts from both natural and anthropogenic sources, which need to be researched in the field to provide a clear understanding of these threats and to contribute to the future of water supplies in the area through planning agencies [6]. Advanced methods, such as

Corresponding author: Reza Attar Nejad, School of Civil Engineering, University of Tehran, Tehran, Iran. E-mail: r.education@mail.ru 
contaminant diffusion and risk management models, for evaluating contamination groundwater vulnerability are not generally realistic for planning agencies. Additionally, indexing approaches are more favored and generally used [7-14]. In methods of this type, geological and hydrogeological variables are rated and weighted in a direct combination to give a contamination vulnerability index for a given location. The index numbers for different locations are then transferred to the environmental map for decision making. Among the variety of intrinsic vulnerability assessment methods, the DRASTIC method was proved to be a suitable and widely used method. Many of the modifications to the irregular index method were made to either change the number of parameters or to strengthen the parameter calculation procedures [15-23]. The novelty of this study comprises, for the first time, discover a map of irrigation water (SI) in the Basara Basin through integrating aquifer vulnerability index and irrigation water quality index. The Pesticide DRASTIC (which is a special case for the standard DRASTIC index) was used for finding the vulnerability index. The water quality index was obtained by collecting hydrochemical data laboratory tests for physical and chemical properties. The other objective was to divide the studied area into segments according to a growing level of susceptibility, water quality, and pesticide DRASTIC indices.

This work is important for decision-makers in the basin to know where there is a risk in the basin and to take necessary measures towards conserving groundwater sources.

\subsection{Study Design}

The Basara basin is situated $25 \mathrm{~km}$ west of Sulaimani city, and lies between 496652 - 537752 East and 3911038 - 3951906 North in the Universal Transfers Mercator (UTM) zone 38 N. It takes up an area of about $571 \mathrm{~km}^{2}$ (Figure 1). Basara basin extends south-westwards from Sulaymani city towards Chamchamal District. The basin is morphologically divided into three subbasins, Bazian, Hanjeera, and Tile. The surface waters are not traditionally used by farmers and industrial facilities because of the low flow rate in the dry season. In the summer period, the streams usually drying out towards the northwest, while there is a minimal flow in the southwest (Figure 2). Tectonically, the basin is located in the unstable platform of the Arabian Plate within the Zagros fold-thrust belt, exactly along the southwestern boundary of the High Folded with Foot Hill Zones of this belt with intense folding and faulting, which resulted from several phases of deformations during Alpine Orogeny [24, 25]. (Figure 3). The maximum Averages monthly temperature was around $40 \mathrm{C}^{0}$ in July and August while the lowest average degree was around $2 \mathrm{C}^{0}$ recorded in January and February. The mean annual rainfall for the years $1980-2018$ was about $(670 \mathrm{~mm})$ based on data obtained from Sulaymannyah and Bazian metrological stations. This basin is a very rich agricultural area, with industrial sites concentrated in the center and north-west of the studied area. Almost all irrigation and industrial water requirement in the basin have been provided by groundwater resources. The distribution of the main potential sources of contamination is shown in Figure 4.

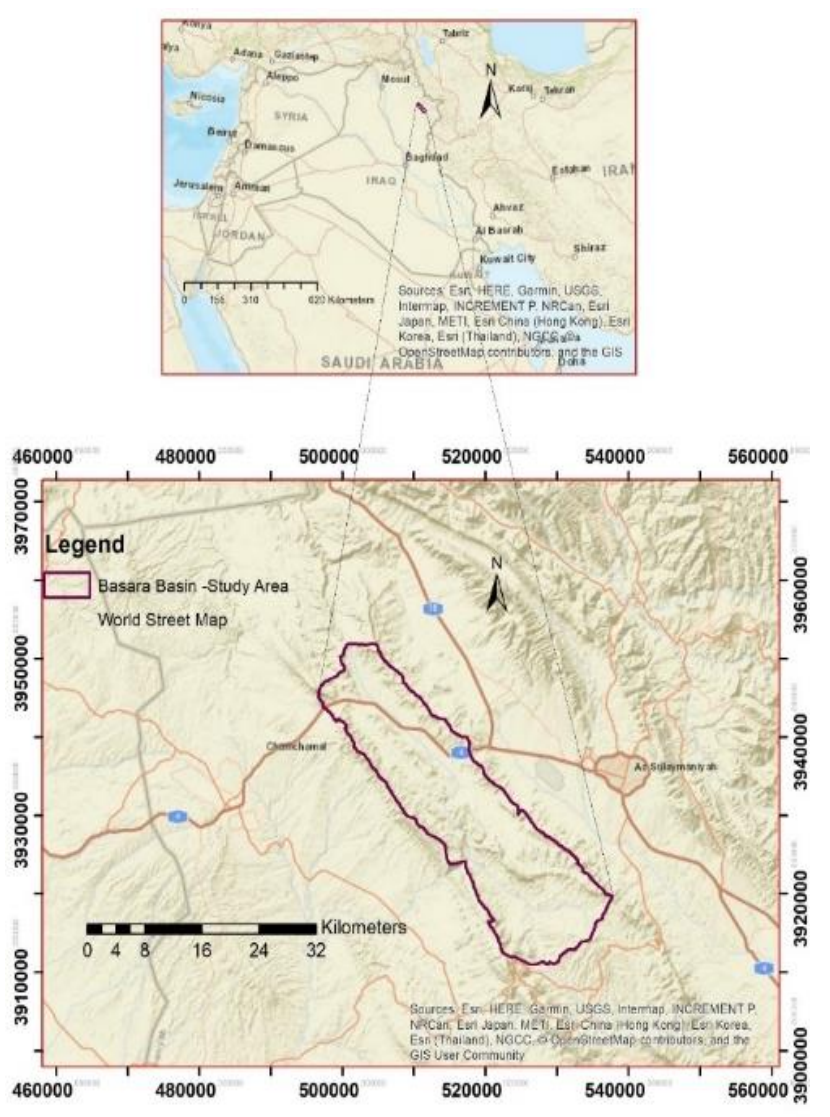

Figure 1: a) Basara Basin-Study Area and b) The perspective of the position

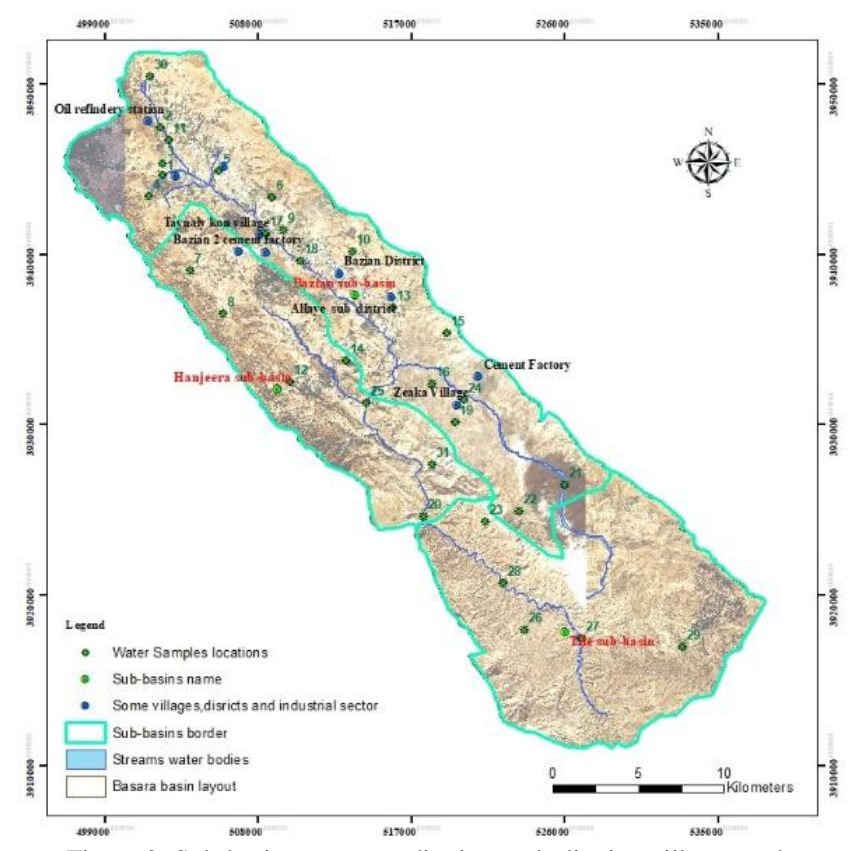

Figure 2: Sub-basins, streams, districts, sub-district, villages and industrial sectors, with water sampling locations in the Basara basin 


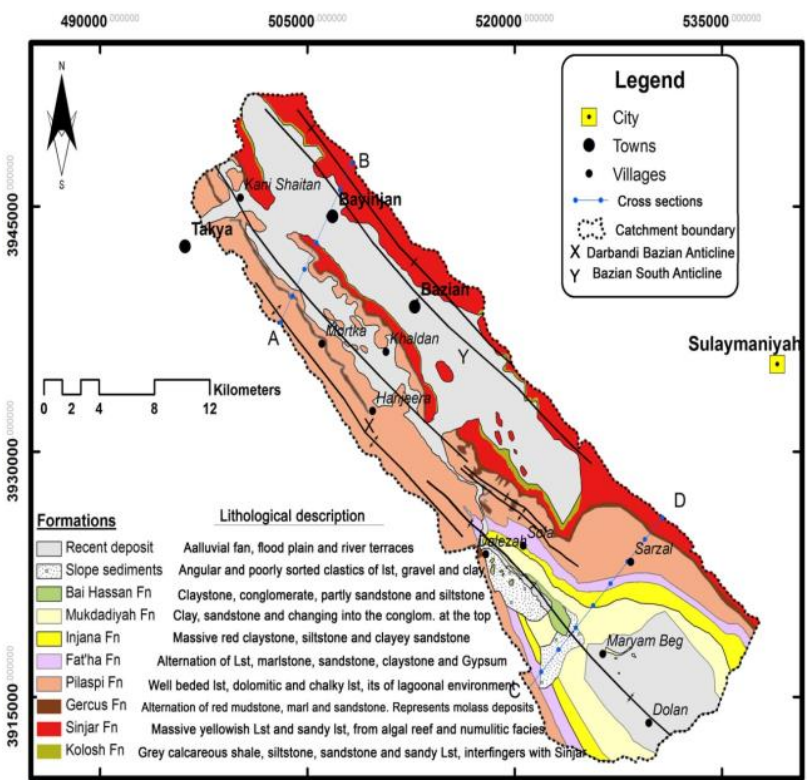

Figure 3: Geological map of the area under study, simplified after [26]

Figure 4 was drawn up by field visits to the site to monitor the position of potential sources of contamination in the region using the Global Position System (GPS) instrument. The available data and satellite image with a resolution of $(0.60 * 0.60$ meters $)$ for the region under research was given by the Department of Statistics of the Sulaymani Province. Finally, all information was inserted in the Geological Information System (GIS-10.5) database to produce the results.

\section{Materials and Method}

The contamination susceptibility index (SI) was computed by taking the multiplication of the vulnerability index (VI) and the quality index QI: SI = VI *QI [11,27]. The DRASTIC model [28] based on the hydrogeology setting was used for the vulnerability indicator calculations. This method applies a set of seven hydrogeological parameters to assign the contamination vulnerability of an aquifer. Parameters are Depth to groundwater (D); Total Recharge (R), Aquifer Media (A), Soil Media (S), Topography-Percent Slope (T), Vadose Zone Influence (I) and Aquifer Hydraulic Conductivity (C), (Table 1). Relevant parameter groups of each parameter represent ranges that are ranked from 1 to 10 based on their relative impact on aquifer vulnerabilities. All seven characteristics have been mapped and translated to a raster format. The seven raster maps were compounded by their weights and added together to create the overall, spatially dispersed map of the intrinsic vulnerability. The vulnerability index based on the DRASTIC method at a specified location can be calculated using the following mathematical statement: VI $=\sum\left(\mathrm{Wp}^{*} \mathrm{Rp}\right)$. Where summation is overall DRASTIC parameters, $\mathrm{Rp}$ is the rate of the parameter at a given position and $\mathrm{Wp}$ is the weight assigned to the related parameter [28] The methods for the calculation of the rate and the weights of the parameters are set down in $[15,29]$ The weight assigned to the Pesticide DRASTIC Models as shown in (Table 1).

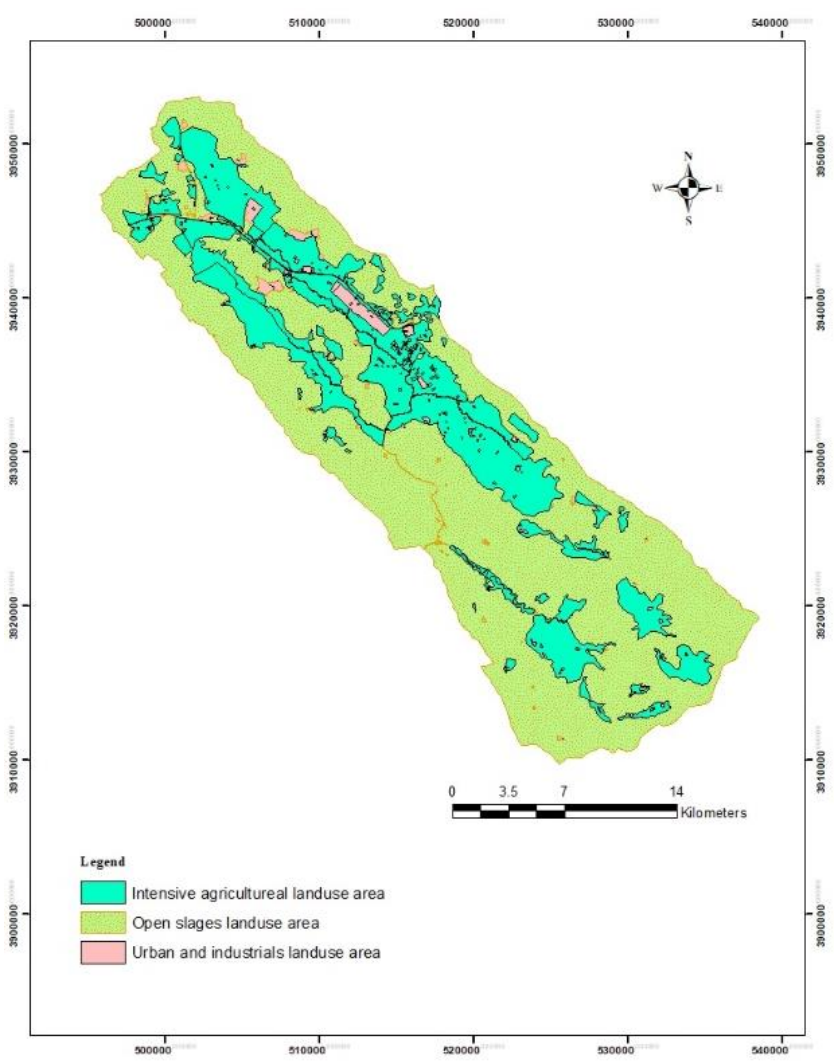

Figure 4: Potential contamination sources- Basara basin

Table 1: Definition and weights of the DRASTIC parameters

\begin{tabular}{llll}
\multicolumn{3}{c}{$[30,15]$} \\
Acronym & Denotes & $\begin{array}{l}\text { Generic } \\
\text { DRASTIC } \\
\text { Weight }\end{array}$ & $\begin{array}{l}\text { Pesticide } \\
\text { DRASTIC } \\
\text { weight }\end{array}$ \\
\hline D & Depth to water & 5 & 5 \\
R & Net recharge & 4 & 4 \\
A & Aquifer media & 3 & 3 \\
S & Soil media & 2 & 5 \\
T & $\begin{array}{l}\text { Topography } \\
\text { Impact of the vadose }\end{array}$ & 1 & 3 \\
I & $\begin{array}{l}\text { zone } \\
\text { Hydraulic conductivity } \\
\text { of the aquifer }\end{array}$ & 3 & 4 \\
C & & 2 \\
\hline
\end{tabular}

The seven DRASTIC parameters and their rates were obtained from previous studies conducted in the Basara basin by (Hamamin, 2011). The distributed value of each parameter was rated in each cell of the grid map of $0.6 \mathrm{~m}$ by $0.6 \mathrm{~m}$ cell dimension. the vulnerability index was created by overlaying the seven thematic layers using the intersect function of the analysis tool in the GIS arc map. The score of the DRASTIC Index (DI) is a dimensionless unit. The site with the largest DI was found extremely likely to become polluted. Thirty-one water samples were collected and chemically analyzed in July (dry season) and April (wet season) of the year 2018. The samples cover groundwater, springs, and streams in the area under study. The stations of the sampling shown in (Figure 2). 
Groundwater samples obtained from wells, two or three meters below the groundwater level, using pumping stations. Samples were gathered after a period of pumping when the field parameters (e.g. Electrical Conductivity EC, and $\mathrm{pH}$ ) indicated constant values. Water samples were carried out in plastic containers and laboratory analysis was organized within 24 hours. The collected samples were analyzed for $\mathrm{pH}$ using $\mathrm{PH}$ meter, Electrical conductivity Total Dissolved Solids (TDS) by using conductivity meter and probe (Aquslytic SD320Con). The amounts of Sodium $\left(\mathrm{Na}^{+}\right)$and Potassium $\left(\mathrm{K}^{+}\right)$were found by Flemo-photometer (EPG450). Calcium $\left(\mathrm{Ca}^{2+}\right)$ and Magnesium $\left(\mathrm{Mg}^{2+}\right)$ were determined by titration with standard Ethylene diamine tetra-acetic acid (EDTA). Chlorides $\mathrm{Cl}^{-}$were found by standard Silver Nitrate titration, Nitrate $\left(\mathrm{NO}^{-}\right.$were tested by using Multi-Parameter Bench Photometer HI 83200. Sulfate $\left(\mathrm{SO}_{4}^{2}\right)$ was found by Spectrophotometer (Aqualytic AL800) and bicarbonate $\left(\mathrm{HCO}^{-}\right)$by titration.

Temperature, electrical conductivity, and $\mathrm{pH}$ were tested in the field. The concentration amounts of cations: $\mathrm{Ca}^{2+}, \mathrm{Mg}^{2+}, \mathrm{Na}^{+}$, $\mathrm{K}^{+}$, Anions: Sulfate $\mathrm{SO}_{4}{ }^{2-}$, chloride $\mathrm{Cl}^{-}$, bicarbonate $\mathrm{HCO}^{-}$and Nitrate $\left.\mathrm{NO}_{3}{ }^{-}\right)$and heavy metals $\left(\mathrm{Mn}, \mathrm{Pb}^{2+}, \mathrm{Zn}^{2+}, \mathrm{Cu}^{2+}, \mathrm{Fe}^{2+}, \mathrm{CO}^{2+}\right.$, $\mathrm{Ni}^{2+}, \mathrm{Cr}^{3+}$, and $\mathrm{As}^{5+}$ ) were determined by the laboratories of Kurdistanian research center in Sulaymaniyah Iraq and Faculty of base science at Tarbyat Mudares University in Tehran Iran using ICP- OES, instrument. The spatial analysis was conducted using the software ArcGIS 10.5. The interpolation kriging technique in Arc GIS has been used to interpolate minimal data to reflect the overall studied area. The analytical methods used to measure the water chemical composition are reported in (Table 2).

Table 2: The analytical methods for measuring water chemical composition

\begin{tabular}{ll}
\hline \multicolumn{2}{l}{ Chemical composition elements and analytical methods } \\
\hline Elements & Analytical method \\
$\mathrm{PH}$ & PH meter \\
$\mathrm{EC}$ & Conductivity meter \\
$\mathrm{Cl}^{-}(\mathrm{mg} / \mathrm{l}), \mathrm{HCO}_{3}{ }^{-}$ & Standard Silver Nitrate titration \\
$\mathrm{SO}^{2-}(\mathrm{mg} / \mathrm{l})$ & Spectrophotometer (Aqualytic \\
$\mathrm{Na}^{+}(\mathrm{mg} / \mathrm{l}), \mathrm{K}+$ & AL800) \\
$\mathrm{NO}_{3}{ }^{-}(\mathrm{mg} / \mathrm{l})$ & Flemo-photometer (EPG450 \\
& HI 83200 Multiparameter Bench \\
$\mathrm{EC}, \mathrm{TDS}$ & $\begin{array}{l}\text { Photometer } \\
\text { Total Hardness TH, } \mathrm{Ca}^{2+}, \mathrm{Mg}^{2+}\end{array}$ \\
\hline
\end{tabular}

The quality index computation is based on the quality categories of ions, which were determined to take the concentrations of ions of water samples at the given locations. In this application, the irrigation water quality classification $[27,31]$ was used, it also mentioned by [7, 32]. In irrigation classification, five groups for each ion concentrations were assigned as excellent (I), good (II), permissible (III), doubtful (IV), and unsuitable (V). The classification limits counted in this study for the parameters considered are shown in (Table 3). The quality index at given locations can be calculated by applying the following formulation: $\mathrm{QI}=\sum(\mathrm{Ci}) 2$. Where summation is overall considered quality parameters. $\mathrm{C}$ is the determined categories of the parameter, $\mathrm{i}$ (ion), as an integer number (from 1 to 5) at a specific location. The second power of $\mathrm{C}$ was used to increase the performance of unsatisfactory output groups in the table [11]. The only concentration that poses a threat to the application of irrigation was considered in this study. By other means, concentrations of the other ions do not present any threat to irrigation applications at present. The dry season (pumping period) values of the measured parameters, which were used in this study, are listed in (Table A1) in the appendix.

\section{Results}

The vulnerability index map in the generic DRASTIC model was prepared previously for the Basara basin in a GIS environment by [35], we use the same parameter maps and their rates for preparing the pesticide DRASTIC method by using weights described in (Table 1). Distributions of the DRASTIC parameter values were determined and a grid map made of $0.6 \mathrm{~m}$ by $0.6 \mathrm{~m}$ cell dimensions were established for each parameter. The distributed values of each parameter were then rated in each cell of the overlay process (Arc map GIS 10.5). Hence, the individual pesticide DRASTIC parameter layers ground on these rated cell values were established in vector form. Eventually, the vulnerability index was calculated for the specified cell, after converting vector forms to raster, by utilizing the rated cell values of the parameters in the vulnerability index equation. The vulnerability index map represents in (Figure 6) was created by dividing the index scope into five groups and defining the boundaries of the groups with polygons. These class groups were also used by [12]. The lowest index value on the map was (51), point out the least vulnerable areas and the maximum index value was (221), indicating the very vulnerable areas to the contamination.

Table 3: Irrigation water classification limits of the parameters used in quality index calculations

\begin{tabular}{llllll}
\hline Parameters & \multicolumn{5}{c}{ Irrigation water limits } \\
\cline { 2 - 6 } & Class, I Excellent & Class II Good & Class III Permissible & Class IV Doubtful & Class V Unsuitable \\
\hline EC $\mu$ slcm & $0-250$ & $251-750$ & $751-2000$ & $2001-3000$ & $>3000$ \\
TDS mg/l & 175 & $175-525$ & $525-1400$ & $1400-2100$ & $>2100$ \\
$\mathrm{Na} \%$ & 20 & $20-40$ & $40-60$ & $60-80$ & $>80$ \\
$\mathrm{PH}$ & 6.5 & $6.5-6.8$ & $6.8-7$ & $7-8$ & $>8$ \\
$\mathrm{NO}_{3}^{-}$ & $0-5$ & $5-10$ & $10-30$ & $30-50$ & $>50$ \\
Total Hardness TH & $<50$ & $50-75$ & $75-150$ & $150-300$ & $>300$ \\
\hline
\end{tabular}

The limits are after $[31,33,34]$ for irrigation water 


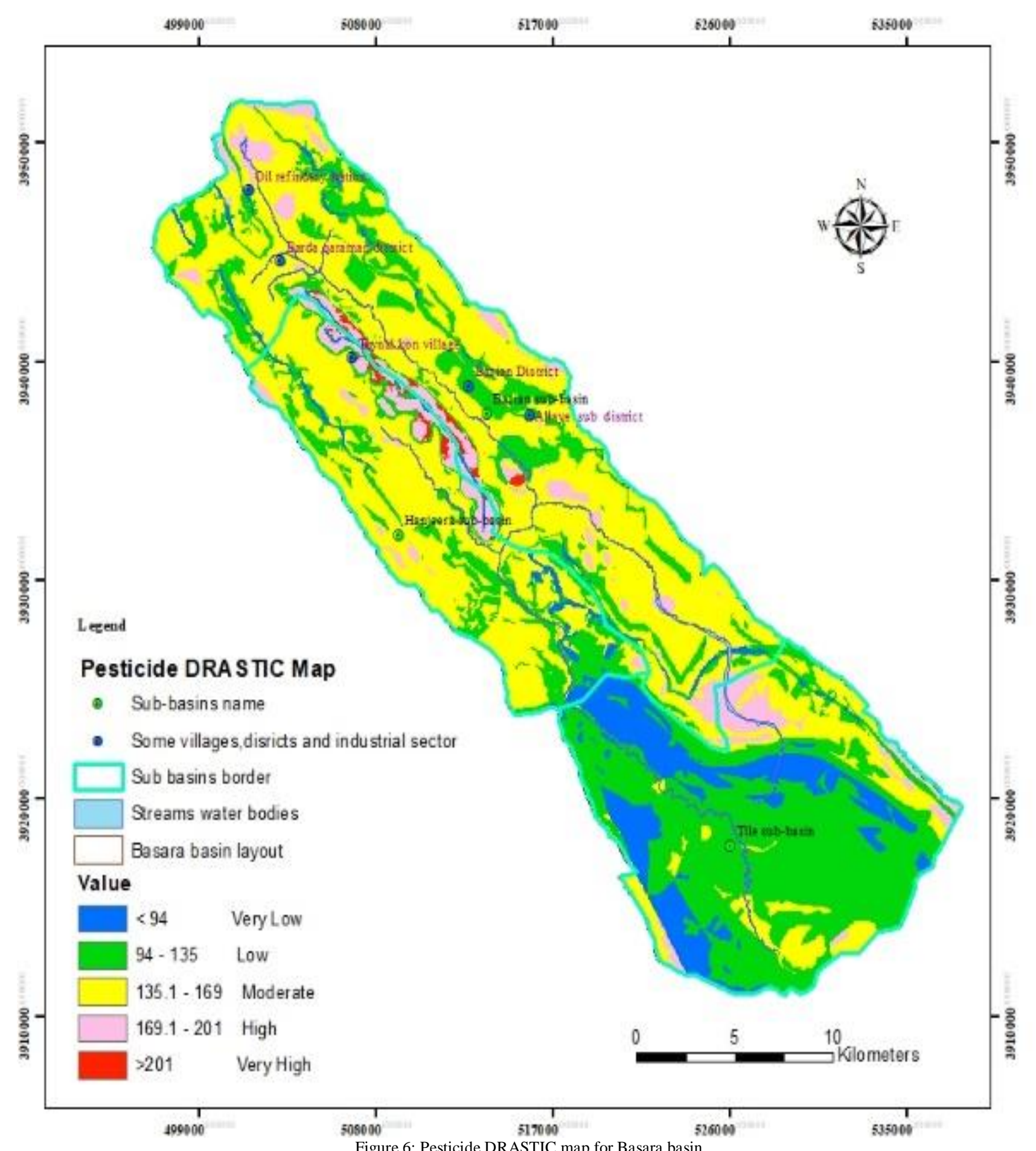

The quality index for quality classes were determined for each sampling location by taking the measured ions values. In the preparation of the quality index map, only (EC, TDS, NO3-, PH, and $\mathrm{Na} \%$ ) parameters were taken into consideration because concentrations of the other ions do not currently present any danger to the irrigation applications. In other words, the quality categories of these ions are all be equivalent to class (I) (Excellent) (Table 3). As the second step, the founded irrigation water quality classes of each considered ions (ranging from I to $\mathrm{V}$ ) changed over to the integer numeric numbers (1 to 5) for all the observing data and then the quality index was deliberated for each sampling locations by using the equation $\mathrm{QI}=\sum(\mathrm{Ci}) 2$ (Table 
A2) in the appendix. The determined results for all water sample locations of (Table A2) were used to create the irrigation water quality index map. The quality index map was prepared in a GIS environment by creating a shape file using water samples location coordinates with the relating quality index in vector form. The vector converted to raster after the kriging interpolation process. The calculated quality indices were separated into six groups because six ions parameters were considered. The minimum possible value of the index was 55, showing the areas with the highest water quality for irrigation. The highest possible value of the quality index was 63 , pointing out the areas with the minimum water quality for irrigation (Figure 7). Finally, the contamination susceptibility index (SI) map for irrigation water was calculated by applying the equation; SI $=$ VI $*$ QI $[11,27]$. For applying this equation, the map algebra process was used in ArcGIS software for multiplying (VI-map) and (QI-map) (Figure 6) and (Figure 7) respectively (Figure 8). The index distribution was classified under five groups and the limits of the groups were defined with polygons. For each group, the occupied and percent area of SI and pesticide DRASTIC classes were shown in (Table 6). The minimum (SI) value varies from 2805 to 13702 . The minimum value, indicating the lowest susceptible areas, and the upper limit index value, indicating the most susceptible areas to contaminations.

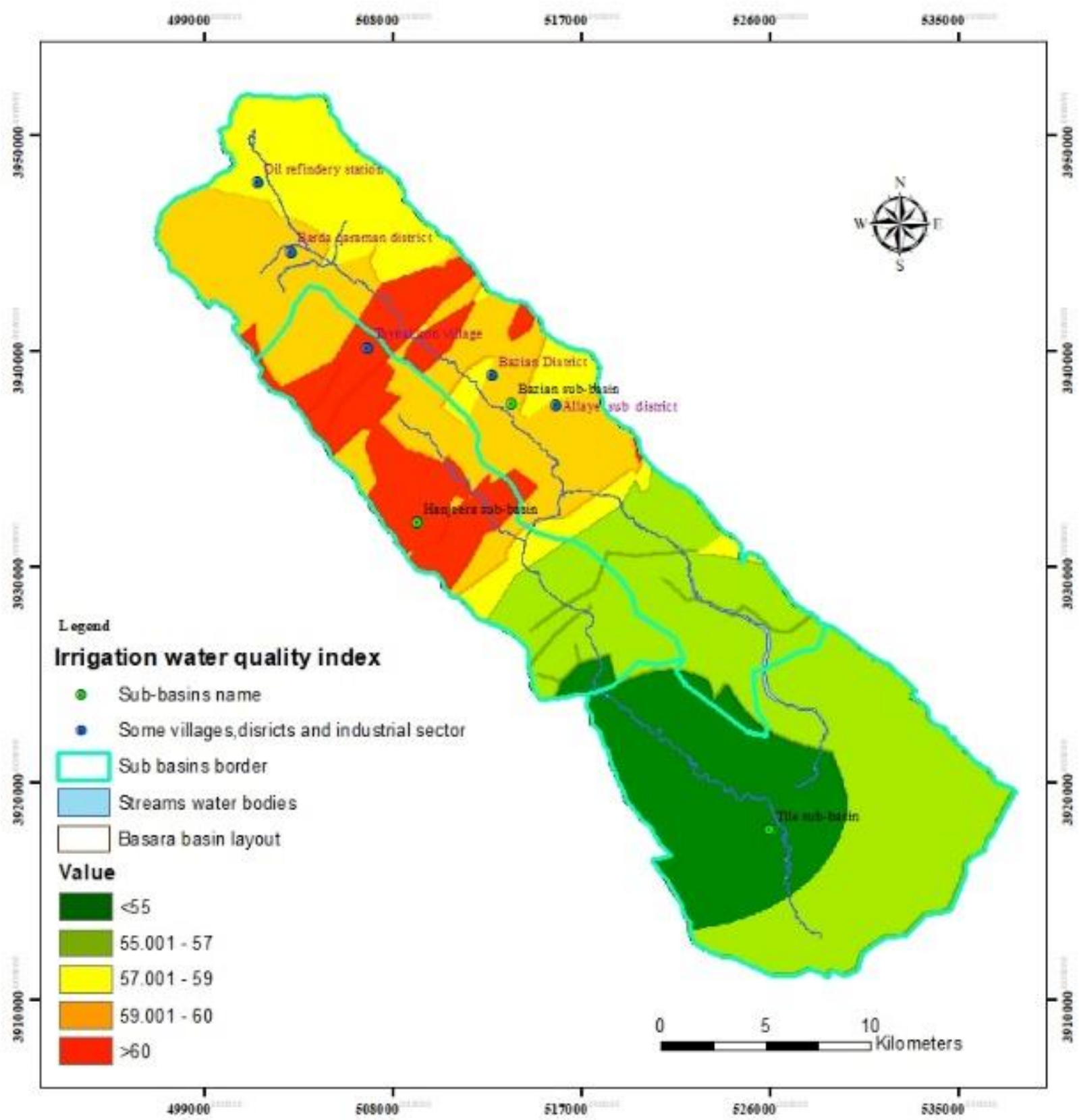

Figure 7: Dry season irrigation water quality index for Basara basin 


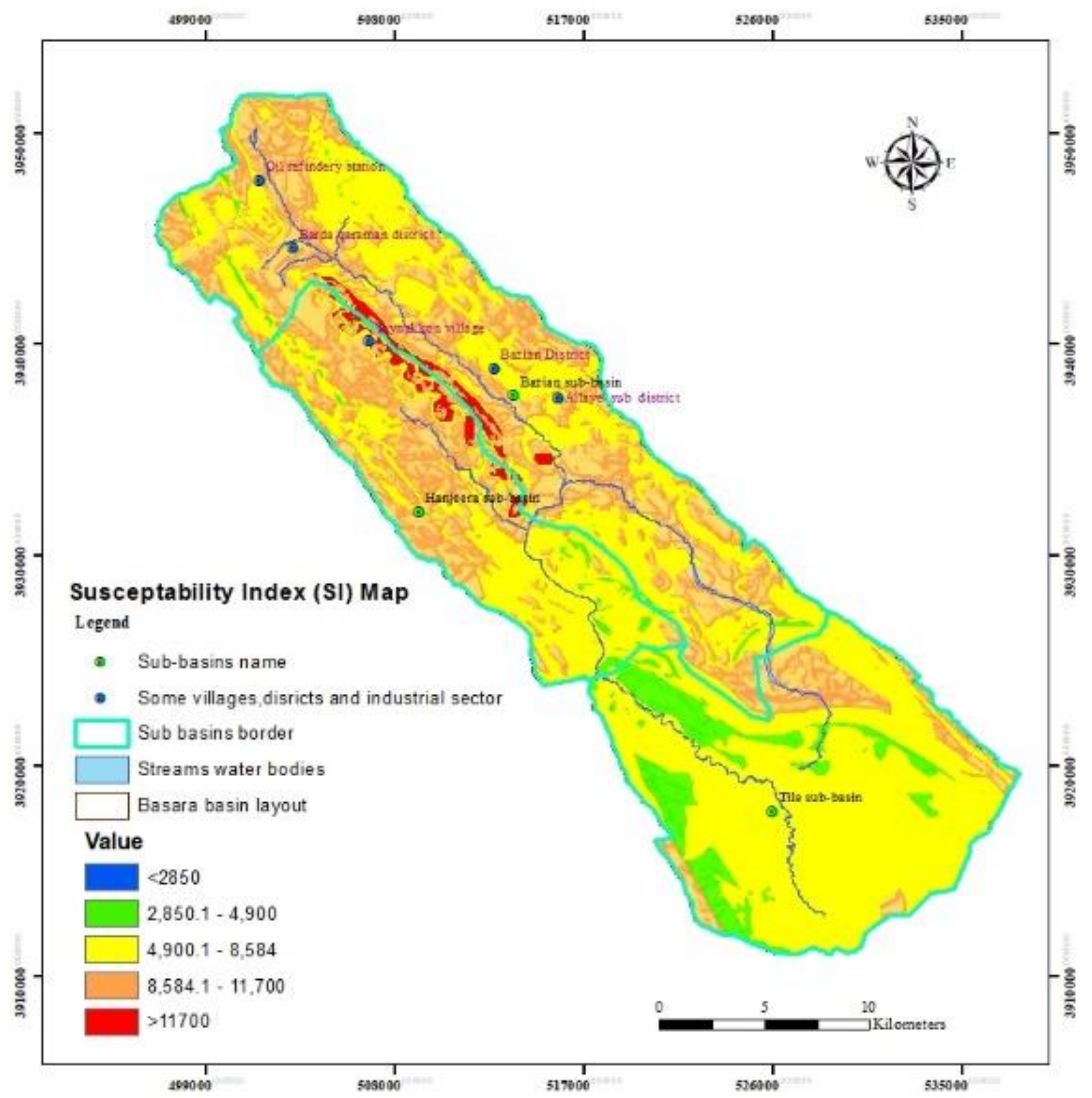

Figure 8: Irrigation water susceptibility index distribution map in the Basara basin

Comparing the results of both SI and pesticide DRASTIC map through (Figure 6) and, (Figure 8) and (Table 6), shows the following results:

1- The percent area occupied in Pesticide map was (very low $9.11 \%$, low $34.67 \%$, moderate $48.04 \%$, high 7.53 and very high $0.65 \%)$, while at SI map the results were $(0.08 \%, 6.08 \%, 53.95 \%$, $38.28 \%$, and $1.61 \%$ ) for the corresponds classes respectively. The SI method reduced the effects of Very Low, and Low classes while it increased the effects of Moderate, High, and Very High.

2- The sub-basin of Tile is less vulnerable to pollution from intrinsic aquifer properties and external contamination. it has good irrigation water quality. The bulk of this basin has a very low and low-class level in the Pesticide DRASTIC Map. QI map indicates that the water qualities vary from 55 to 57 , which is in the minimum range, it is classified as the (best quality) in terms of irrigation. The SI map shows explicitly that the SI value of the most covered area in this sub-basin ranges from 2850 to 8584 , which is equivalent to a very low and low class in the Pesticide DRASTIC map. The distance from the surface to the groundwater in this sub-basin is high, it has the high ground surface slope, with the minimum industrial, agricultural and urbanization activities, these factors have had an active effect on showing the sub-basin as less exposed to pollutants.

3- In contrast, the Bazian and Hangera sub-basins, are more vulnerable to pollution and have poorer agricultural water consistency than the Tile sub-basin. In most of both sub-basin 
areas, the Pesticide DRASTIC index ranges from 94 to 169 (low and moderate classes). The quality of irrigation water, for most of the occupied area in both sub-basins, ranges from 57 to 63, implying low irrigation quality compared to that seen in the Tile sub-basin. The SI map shows that the maximum area covered by these two sub-basins has valued ranges from 4,900 to 11,700 , which correlates to the moderate and high classes on the Pesticide DRASTIC map. The distance to the groundwater in theses subbasins is low, with existing extensive farming, commercial, and urbanization operations, and they have a small slope. Such aspects have a significant effect on the exposure of these subbasins to become more susceptible to contamination.

4- In general, most of the maximum susceptible area in the SI map spreads within the flat areas of both of the streams banks in the Basara basin, which have been used intensively in agricultural operations. The highest value of SI ranges from $(11,700$ to $13,702)$, corresponds to the very high and high levels in the Pesticide DRASTIC map, and distributed in the center of the Basara basin within the border between Bazian and Hangera subbasin. The aquifers in this region have been geologically identified as Karst aquifers, it has high permeability, and the presence of cement factories can be considered as the key cause for the emergence of these regions as the most susceptible areas. These factories use the upper protective layers of these aquifers for cement production, which has led to the elimination of the protective layer of groundwater, and the high permeability of these layers has had an effective effect on spreading contaminations and classifying them as the higher pollution-prone area.

5- In general, the areas were used in intensive industrial sectors such as cement plants, oil refineries, and medium and small industrial sectors, on hurting water quality and has an effective impact on increasing DI and SI. This is a clear message to decision-makers to review the new management plans towards regulating of these industrial operations. It also emphasizes the significance of a geological and hydrogeological study towards building new plans for minimizing threat sources activities in Bazian and Hanjeera sub-basins and using the Tele sub-basin, as an alternate region for reducing the effect of problematic areas in Basara basin.

\section{Conclusion}

Merging the intrinsic Vulnerability Index (VI) through applying the pesticide DRASTIC method, with the irrigation quality index map, to create a susceptibility Index (SI) map according to the equation $\left(\mathrm{SI}=\mathrm{VI}{ }^{*} \mathrm{QI}\right)$ is the main aim of this study. Based on obtained results, the streams direction, the geological formation of aquifers, land slope, and contamination sources have a great impact on water quality, vulnerability, and susceptibility index of the basin. In the pesticide DRASTIC map, the basin was classified into five class as (very low $9.11 \%$, low $34.67 \%$, moderate $48.04 \%$, high 7.53 and very high $0.65 \%$ ), while the SI map classifies them as $(0.08 \%, 6.08 \%, 53.95 \%, 38.28 \%$, and $1.61 \%$ ) for corresponding classes respectively. The SI map has reduced the occupied areas of Very Low, and Low classes comparing with the pesticide DRASTIC. It also increased the occupied areas of Moderate, High, and Very High classes, making the SI map more practical for assessing actual groundwater contamination. The most vulnerable area to pollution were those that used in intensive industrial sectors, areas with high permeability such as Karst aquifers, and areas with mild slopes which were used as an agricultural area. GIS, which has been used to access hydro-chemical and hydrogeological data into a single index of a specific basin, offered a good framework for assessing the susceptibility index at the catchment area. The combined both types of data sets of vulnerability index and quality index generated a more practical estimation in the actual data set to determine the vulnerability of groundwater contamination to the aquifer through the susceptibility index map. The method offers a clearer estimating of the capacity for aquifer pollutants by combining hydro-chemical and hydro-geological data sets. it helps decision-makers viewing towards the quality of irrigation water and more susceptible areas to pollution, it works also as a foundation for future study towards minimizing the influence of problematic areas and preparing new management plan proposals for groundwater resources in the Basara basin.

\section{Acknowledgments}

We would like to present our gratitude to the staff of Sulaimani Technical Institute and School of Civil Engineering, University of Tehran, for their cooperation and contribution.

\section{Ethical issue}

Authors are aware of, and comply with, best practice in publication ethics specifically with regard to authorship (avoidance of guest authorship), dual submission, manipulation of figures, competing interests and compliance with policies on research ethics. Authors adhere to publication requirements that submitted work is original and has not been published elsewhere in any language.

\section{Competing interests}

The authors declare that there is no conflict of interest that would prejudice the impartiality of this scientific work.

\section{Authors' contribution}

All authors of this study have a complete contribution for data collection, data analyses and manuscript writing.

\section{References}

1- Ghalib HB. Groundwater chemistry evaluation for drinking and irrigation utilities in east Wasit province, Central Iraq. Applied Water Science. 2017 Nov 1;7(7):3447-67.

2- Abbasnia A, Radfard M, Mahvi AH, Nabizadeh R, Yousefi M, Soleimani H, Alimohammadi M. Groundwater quality assessment for irrigation purposes based on irrigation water quality index and its zoning with GIS in the villages of Chabahar, Sistan and Baluchistan, Iran. Data in brief. 2018 Aug 1;19:623-31

3- Aghazadeh N, Mogaddam AA. Assessment of groundwater quality and its suitability for drinking and agricultural uses in the Oshnavieh area, Northwest of Iran. Journal of Environmental protection. 2010 Mar 31;1(01):30.

4- Jebastina N, Arulraj GP. GIS based assessment of groundwater quality in Coimbatore district, India. Journal of Environmental and Analytical Toxicology. 2017 Apr 7;7(3):1-9.

5- Neshat A, Pradhan B, Dadras M. Groundwater vulnerability assessment using an improved DRASTIC method in GIS. Resources, Conservation and Recycling. 2014 May 1;86:74-86.

6- Hamamin DF. Hydrogeological assessment and groundwater vulnerability map of Basara Basin, Sulaimani Governorate, Iraq, Kurdistan Region. Unpublished $\mathrm{PhD}$ thesis, College of Science, University of Sulaimani P. 2011;174.

7- Evans BM, Myers WL. A GIS-based approach to evaluating regional 
groundwater pollution potential with DRASTIC. Journal of Soil and Water Conservation. 1990 Mar 1;45(2):242-5.

8- Rosen L. A study of the DRASTIC methodology with emphasis on Swedish conditions. Ground water. 1994 Mar 1;32(2):278-285.

9- Kim YJ, Hamm SY. Assessment of the potential for groundwater contamination using the DRASTIC/EGIS technique, Cheongju area, South Korea. Hydrogeology Journal. 1999 Apr 1;7(2):227-35.

10- Shahid S. A study by groundwater pollution vulnerability using DRASTC/GIS, West Bengal, India. Journal of Environmental Hydrology. 2000;8.

11- Pusatli OT, Camur MZ, Yazicigil H. Susceptibility indexing method for irrigation water management planning: applications to $\mathrm{K}$. Menderes river basin, Turkey. Journal of environmental management. 2009 Jan 1;90(1):341-7.

12- Ahmed AA. Using generic and pesticide DRASTIC GIS-based models for vulnerability assessment of the Quaternary aquifer at Sohag, Egypt. Hydrogeology Journal. 2009 Jul 1;17(5):1203-17.

13- Asadi P, Hosseini SM, Ataie-Ashtiani B, Simmons CT. Fuzzy vulnerability mapping of urban groundwater systems to nitrate contamination. Environmental modelling \& software. 2017 Oct 1;96:146-57.

14- Khosravi K, Sartaj M, Tsai FT, Singh VP, Kazakis N, Melesse AM, Prakash I, Bui DT, Pham BT. A comparison study of DRASTIC methods with various objective methods for groundwater vulnerability assessment. Science of the total environment. $2018 \mathrm{Nov}$ 15;642:1032-49.

15- Aller L. DRASTIC: a standardized system for evaluating ground water pollution potential using hydrogeologic settings. Robert S. Kerr Environmental Research Laboratory, Office of Research and Development, US Environmental Protection Agency; 1985.

16- Rupert MG. Improvements to the DRASTIC ground-water vulnerability mapping method. US Geological Survey.National Water-Quality Assesment Program-NAWQA. 1999. https://doi.org/10.3133/fs06699

17- Murray KS, Rogers DT. Groundwater vulnerability, brownfield redevelopment and land use planning. Journal of Environmental Planning and Management. 1999 Nov 1;42(6):801-10.

18- Fritch TG, McKnight CL, Yelderman Jr JC, Dworkin SI, Arnold JG. A predictive modeling approach to assessing the groundwater pollution susceptibility of the Paluxy Aquifer, Central Texas, using a geographic information system. Environmental Geology. $2000 \mathrm{Jul}$ 1;39(9):1063-9.

19- Fredrick KC, Becker MW, Flewelling DM, Silavisesrith W, Hart ER. Enhancement of aquifer vulnerability indexing using the analyticelement method. Environmental geology. 2004 Jun 1;45(8):1054-61.

20- Jovanovic NZ, Adams S, Thomas A, Fey M, Beekman HE, Campbell R, Saayman I, Conrad J. Improved DRASTIC method for assessment of groundwater vulnerability to generic aqueousphase contaminants. WIT Transactions on Ecology and the Environment. 2006 Jun 1;92.

21- Javadi S, Kavehkar N, Mousavizadeh MH, Mohammadi K Modification of DRASTIC model to map groundwater vulnerability to pollution using nitrate measurements in agricultural areas. J Agric Sci Technol. 2011;13(2):239-249.

22- He H, Li X, Li X, Cui J, Zhang W, Xu W. Optimizing the DRASTIC Method for Nitrate Pollution in Groundwater Vulnerability Assessments: a Case Study in China. Polish Journal of Environmental Studies. 2018 Jan 1;27(1), 95-107.

23- Barzegar R, Asghari Moghaddam A, Norallahi S, Inam A, Adamowski J, Alizadeh MR, Bou Nassar J. Modification of the DRASTIC framework for mapping groundwater vulnerability zones. Groundwater. 2020 May;58(3):441-52.

24- Jassim SZ, Goff JC, editors. Geology of Iraq. DOLIN, sro, distributed by Geological Society of London; 2006.

25- Stevanovic Z, Markovic M. Hydrogeology of Northern Iraq, climate, hydrology, geomorphology and geology. Spec. Edition FAO / UN. 2003:1-122 (63 annexes)

26- Hamamin DF, Ali SS. Hydrodynamic study of karstic and intergranular aquifers using isotope geochemistry in Basara basin,
Sulaimani, North-Eastern Iraq. Arabian Journal of Geosciences. 2013 Aug 1;6(8):2933-40.

27- Saidi S, Bouri S, Dhia HB, Anselme B. A GIS-based susceptibility indexing method for irrigation and drinking water management planning: Application to Chebba-Mellouleche Aquifer, Tunisia. Agricultural Water Management. 2009 Dec 1;96(12):1683-90.

28- Kumar A, Pramod Krishna A. Groundwater vulnerability and contamination risk assessment using GIS-based modified DRASTICLU model in hard rock aquifer system in India. Geocarto International. 2020 Aug 17;35(11):1149-78.

29- Neukum C, Hötzl H. Standardization of vulnerability maps. Environmental Geology. 2007 Jan 1;51(5):689-94.

30- WCCR (Water Contamination Control Regulations). Official Paper. Ankara. 1991;19919.

31- Sedrati N, Djabri L. Contribution of hydrochemistry to the characterization and assessment of groundwater resources: the case of Tebessa alluvial aquifer (Algeria). Proceedings of the International Association of Hydrological Sciences. 2014 Sep 16;364:458-63.

32- Don CM. A grows guide to water quality. University college station, Texas. 1995:601-9.

33- Ayers RS, Westcot DW. Water quality for agriculture. Rome: Food and Agriculture Organization of the United Nations; 1985.

34- Ali SS, Hamamin DF. Groundwater Vulnerability Map of Basara Basin, Sulaimani Governorate, Iraqi Kurdistan Region. Iraqi Journal of Science. 2012;53(3):579-94. 


\section{Appendix}

Table A1: Dry season groundwater, springs and surface water samples concentrations (mg/l) in Basara basin

\begin{tabular}{|c|c|c|c|c|c|c|c|c|c|c|}
\hline $\begin{array}{c}\text { Water } \\
\text { sample } \\
\text { location ID }\end{array}$ & $\begin{array}{l}\text { Description of } \\
\text { the water } \\
\text { samples }\end{array}$ & UTMX & UTMY & $\begin{array}{l}\text { TDS } \\
\mathrm{mg} / \mathrm{l}\end{array}$ & $\begin{array}{c}\text { EC } \\
\mu \mathrm{s} \backslash \mathrm{cm}\end{array}$ & $\mathrm{Na} \%$ & $\begin{array}{c}\mathrm{pH} \\
\mu \mathrm{s} \backslash \mathrm{cm}\end{array}$ & $\begin{array}{c}\mathrm{NO}^{-} \\
\mathrm{mg} / \mathrm{l}\end{array}$ & $\begin{array}{c}\mathrm{SO}^{2-} \\
\mathrm{mg} / 1\end{array}$ & $\begin{array}{c}\text { Total } \\
\text { Hardness } \\
\text { mg/l }\end{array}$ \\
\hline 1 & Surface water & 502404 & 3944671 & 382 & 1431 & 32.86 & 8 & 10.13 & 120 & 316 \\
\hline 2 & Surface water & 502282 & 3947449 & ND & 606 & 14.93 & 7.8 & 12.05 & 123 & 216 \\
\hline 3 & Well & 502359 & 3945361 & 294 & 460 & 3.58 & 8.2 & 10.5 & 35.8 & 332 \\
\hline 4 & Well & 501542 & 3943404 & 297 & 464 & 2.15 & 7.9 & 10.9 & 24.2 & 342 \\
\hline 5 & Well & 505693 & 3944897 & ND & 430 & 1.44 & 8.1 & 10.24 & 20.7 & 520 \\
\hline 6 & Well & 508793 & 3943335 & 212 & 331 & 1.96 & 8 & 32.13 & 13.5 & 266 \\
\hline 7 & Spring & 503981 & 3939024 & 282 & 442 & 2.40 & 7.9 & 13 & 3.6 & 340 \\
\hline 8 & Spring & 505940 & 3936511 & 293 & 458 & 2.42 & 8.1 & 12.89 & 12.3 & 340 \\
\hline 9 & Well & 509456 & 3941407 & 258 & 404 & 3.40 & 8 & 14.77 & 17.8 & 236 \\
\hline 10 & Well & 513551 & 3940143 & 179 & 280 & 2.35 & 8.2 & 13.13 & 11.6 & 186 \\
\hline 11 & Surface water & 502725 & 3946722 & ND & 709 & 8.16 & 8.3 & 11.36 & 17.8 & 320 \\
\hline 12 & Spring & 509826 & 3932541 & 309 & 484 & 2.98 & 8.2 & 32.13 & 8.3 & 310 \\
\hline 13 & Well & 515897 & 3936844 & 732 & 1144 & 3.60 & 7.8 & 8.68 & 65 & 500 \\
\hline 14 & Spring & 513125 & 3933774 & 254 & 398 & 3.40 & 8 & 21.69 & 6.1 & 290 \\
\hline 15 & Spring & 519069 & 3935353 & 176 & 276 & 2.57 & 8.5 & 16.41 & 3.3 & 230 \\
\hline 16 & Spring & 518219 & 3932409 & 294 & 460 & 4.09 & 8.3 & 19.12 & 2.4 & 300 \\
\hline 17 & Surface water & 508407 & 3941223 & ND & 567 & 6.65 & 8.3 & 14.37 & 16.6 & 284 \\
\hline 18 & Surface water & 510487 & 3939631 & ND & 552 & 6.99 & 8.5 & 14 & 18.3 & 302 \\
\hline 19 & Well & 519591 & 3930129 & 206 & 322 & 2.94 & 8.6 & 15.5 & 24.3 & 204 \\
\hline 20 & Surface water & 517688 & 3924606 & ND & 521 & 5.29 & 8.5 & 9.77 & 11.7 & 282 \\
\hline 21 & Spring & 526007 & 3926479 & 382 & 598 & 3.35 & 8.1 & 11.8 & 9.7 & 360 \\
\hline 22 & Spring & 523300 & 3924898 & 298 & 466 & 3.11 & 8 & 7.64 & 4.7 & 290 \\
\hline 23 & Spring & 521338 & 3924309 & 316 & 495 & 4.00 & 7.9 & 6.95 & 15.9 & 280 \\
\hline 24 & Surface water & 520092 & 3931445 & ND & 459 & 36.70 & 8.5 & 17.31 & 9.7 & 224 \\
\hline 25 & Surface water & 514344 & 3931242 & ND & 531 & 6.29 & 8.4 & 22.78 & 12.1 & 296 \\
\hline 26 & Spring & 523616 & 3917945 & 293 & 458 & 1.90 & 7.9 & 6.48 & 14 & 338 \\
\hline 27 & Well & 526997 & 3917465 & 396 & 618 & 2.28 & 7.9 & 6.95 & 36.8 & 328 \\
\hline 28 & Surface water & 522386 & 3920665 & 357 & 558 & 5.79 & 8.4 & 6.26 & 15.8 & 330 \\
\hline 29 & Surface water & 532900 & 3916920 & 383 & 599 & 4.07 & 7.9 & 8.68 & 7 & 320 \\
\hline 30 & Well & 501637 & 3950466 & ND & 436 & 2.91 & 8.4 & 12.26 & 5 & 252 \\
\hline 31 & Spring & 518172 & 3927633 & ND & 556 & 2.61 & 7.7 & 10.43 & 4.4 & 325 \\
\hline
\end{tabular}


Table A2: Water quality integer classes for monitoring data of the Basara basin

\begin{tabular}{|c|c|c|c|c|c|c|c|c|c|c|}
\hline $\begin{array}{l}\text { Water } \\
\text { sample } \\
\text { location } \\
\text { ID }\end{array}$ & $\begin{array}{l}\text { Description of } \\
\text { the water } \\
\text { samples }\end{array}$ & UTM X & UTM Y & $\begin{array}{c}\text { TDS } \\
\text { CLASS }\end{array}$ & $\begin{array}{c}\text { EC } \\
\text { CLASS }\end{array}$ & $\begin{array}{c}\mathrm{Na} \% \\
\text { CLASS }\end{array}$ & $\begin{array}{c}\text { PH } \\
\text { CLASS }\end{array}$ & $\begin{array}{c}\mathrm{NO}^{-} \\
\text {CLASS }\end{array}$ & $\begin{array}{c}\text { Total } \\
\text { Hardness } \\
\text { CLASS }\end{array}$ & $\mathrm{QI}=\sum(\mathrm{Ci})^{2}$ \\
\hline 1 & Surface water & 502404 & 3944671 & 2 & 3 & 2 & 4 & 3 & 5 & 67 \\
\hline 2 & Surface water & 502282 & 3947449 & 1 & 2 & 1 & 4 & 3 & 4 & 47 \\
\hline 3 & Well & 502359 & 3945361 & 2 & 2 & 1 & 5 & 3 & 5 & 68 \\
\hline 4 & Well & 501542 & 3943404 & 2 & 2 & 1 & 4 & 3 & 5 & 59 \\
\hline 5 & Well & 505693 & 3944897 & 2 & 2 & 1 & 5 & 3 & 5 & 68 \\
\hline 6 & Well & 508793 & 3943335 & 2 & 2 & 1 & 4 & 4 & 4 & 57 \\
\hline 7 & spring & 503981 & 3939024 & 2 & 2 & 1 & 4 & 3 & 5 & 59 \\
\hline 8 & spring & 505940 & 3936511 & 2 & 2 & 1 & 5 & 3 & 5 & 68 \\
\hline 9 & Well & 509456 & 3941407 & 2 & 2 & 1 & 4 & 3 & 4 & 50 \\
\hline 10 & Well & 513551 & 3940143 & 2 & 2 & 1 & 5 & 3 & 4 & 59 \\
\hline 11 & Surface water & 502725 & 3946722 & 1 & 2 & 1 & 5 & 3 & 5 & 65 \\
\hline 12 & spring & 509826 & 3932541 & 2 & 2 & 1 & 5 & 4 & 5 & 75 \\
\hline 13 & Well & 515897 & 3936844 & 3 & 3 & 1 & 4 & 2 & 5 & 64 \\
\hline 14 & spring & 513125 & 3933774 & 2 & 2 & 1 & 4 & 3 & 4 & 50 \\
\hline 15 & Spring & 519069 & 3935353 & 2 & 2 & 1 & 5 & 3 & 4 & 59 \\
\hline 16 & Spring & 518219 & 3932409 & 2 & 2 & 1 & 5 & 3 & 5 & 68 \\
\hline 17 & Surface water & 508407 & 3941223 & 1 & 2 & 1 & 5 & 3 & 4 & 56 \\
\hline 18 & Surface water & 510487 & 3939631 & 1 & 2 & 1 & 5 & 3 & 5 & 65 \\
\hline 19 & Well & 519591 & 3930129 & 2 & 2 & 1 & 5 & 3 & 4 & 59 \\
\hline 20 & Surface water & 517688 & 3924606 & 1 & 2 & 1 & 5 & 2 & 4 & 51 \\
\hline 21 & spring & 526007 & 3926479 & 2 & 2 & 1 & 5 & 3 & 5 & 68 \\
\hline 22 & spring & 523300 & 3924898 & 2 & 2 & 1 & 4 & 2 & 4 & 45 \\
\hline 23 & spring & 521338 & 3924309 & 2 & 2 & 1 & 4 & 2 & 4 & 45 \\
\hline 24 & Surface water & 520092 & 3931445 & 1 & 2 & 2 & 5 & 3 & 4 & 59 \\
\hline 25 & Surface water & 514344 & 3931242 & 1 & 2 & 1 & 5 & 3 & 4 & 56 \\
\hline 26 & spring & 523616 & 3917945 & 2 & 2 & 1 & 4 & 2 & 5 & 54 \\
\hline 27 & Well & 526997 & 3917465 & 2 & 2 & 1 & 4 & 2 & 5 & 54 \\
\hline 28 & Surface water & 522386 & 3920665 & 2 & 2 & 1 & 5 & 2 & 5 & 63 \\
\hline 29 & Surface water & 532900 & 3916920 & 2 & 2 & 1 & 4 & 2 & 5 & 54 \\
\hline 30 & Well & 501637 & 3950466 & 1 & 2 & 1 & 5 & 3 & 4 & 56 \\
\hline 31 & Spring & 518172 & 3927633 & 1 & 2 & 1 & 4 & 3 & 5 & 56 \\
\hline
\end{tabular}

